\title{
ROAD TRAFFIC SAFETY DEVELOPMENT TRENDS IN LATVIA
}

\author{
JURIS KREICBERGS ${ }^{2,3^{*}}$, JURIS SMIRNOVS ${ }^{1}$, ALDIS LAMA ${ }^{2}$, \\ JANIS SMIRNOVS ${ }^{1}$, ATIS ZARINS ${ }^{1}$ \\ ${ }^{1}$ Department of Roads and Bridges, Transportation Engineering Institute, \\ Faculty of Civil Engineering, Riga Technical University, Riga, Latvia \\ ${ }^{2}$ Latvian Road Traffic Safety Directorate, Riga, Latvia \\ ${ }^{3}$ Department of Automotive Engineering, Transport Institute, \\ Faculty of Mechanical Engineering, Transport and Aeronautics, \\ Riga Technical University, Riga, Latvia
}

Received 7 July 2021; accepted 3 October 2021

\begin{abstract}
The main focus of this article is on the road traffic safety development trends in Latvia. Soon after the regain of independence at the beginning of the 1990s, road traffic safety characteristics in Latvia were the worst in the Latvian history. The increase of car availability and affordability made the car a major road vehicle. The implementation of road safety programmes contributed to essential improvement of road traffic safety in Latvia. The number of road accident fatalities in 2020 compared to 1991 decreased more than sevenfold. Nevertheless, the current Latvian road traffic safety statistics is well below the average level of the EU member states and even the pandemics did not cause similar reduction as in most member states. This indicates that great improvement is still needed. The article shows the Latvian experience in road traffic safety enhancements and discusses the measures to improve road traffic safety.
\end{abstract}

Keywords: road traffic safety, road fatalities, car ownership, vehicle mileage, traffic accidents, drivers, traffic safety indicators.

\footnotetext{
* Corresponding author. E-mail: Juris.Kreicbergs@rtu.lv Juris SMIRNOVS (ORCID ID 0000-0003-3709-7179)

Copyright (C) 2021 The Author(s). Published by RTU Press

This is an Open Access article distributed under the terms of the Creative Commons Attribution License (http://creativecommons.org/licenses/by/4.0/), which permits unrestricted use, distribution, and reproduction in any medium, provided the original author and source are credited.
} 


\section{Introduction}

In Latvia as in most of the EU countries, more than $80 \%$ of inland transport passenger-kilometres are covered by cars, having much higher passenger transportation share than buses, trains and motor coaches (Eurostat, 2020b). Concerning the ton-kilometre volumes of goods transport in Latvia, railway plays a major role contributing to $75 \%$ of goods transportation in 2018 (Eurostat, 2020a). Inroad vehicle traffic is continuing to increase and in 2017 it reached 5085 vehicles/hour. Road traffic still makes a huge challenge for the society causing an essential number of human life losses, injuries and losses both to welfare and country economics.

Since the early 1990s, the number of road fatalities in Latvia has essentially decreased. Nevertheless, losses to Latvian national economy are still considerable and in 2020 amounted up to 209 million EUR (CSDD, 2021a) or to 110 EUR per capita.

The aim of this paper is to show the Latvian experience of road traffic safety improvement and to discuss the measures to improve road traffic safety level.

\section{Data sources and used methods}

The main data sources for this research are statistics from the Road Traffic Safety Directorate and Central Bureau of Statistics. The Road Traffic Safety Directorate has provided data about the number of registered vehicles and road traffic accidents since 1960, as well as information about drivers since 1996. Data about the number of inhabitants has been provided by the Central Bureau of Statistics. There is no division in urban and rural areas in this research. The gained results provide a general report on the Latvian road traffic safety.

\subsection{Exposure data}

Information about the number of registered vehicles, number of inhabitants and drivers, road network length and traffic volume is used as exposure data.

\subsubsection{Car ownership and vehicle fleet}

The first car was brought to Latvia in 1896. It was a model produced by Panhard et Levassor (Gromule, 2020). In 1930, just a few decades later there were already 2975 vehicles, 1950 of them were cars and 1025 were commercial vehicles (Bureu de Statistique de l'État, 1930).
Janis Smirnovs,

Atis Zarins

Road Traffic Safety Development Trends in Latvia 


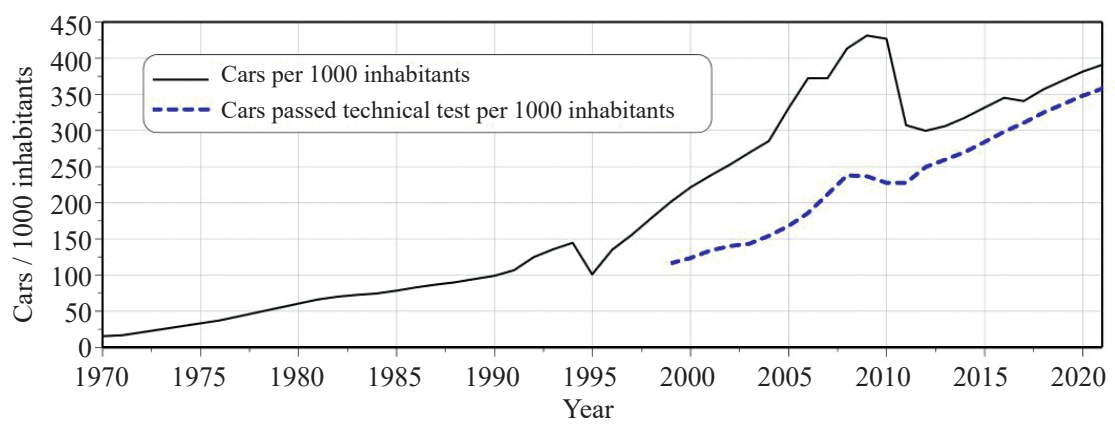

Figure 1. Car ownership growth in Latvia

The most popular car brand at that time was Chevrolet represented by 417 units. Until the beginning of the 1990s, car usage developed slowly and evenly by reaching 100 cars/1000 inhabitants in 1990 only (see Fig. 1). Starting from the 1990s, car ownership developed at an increasing speed by reaching its peak in 2007 and 2008 when the vehicle fleet increased by $10 \%$ per year. From the graph of registered cars per 1000 inhabitants it seems that the economic crisis in the following years led to car fleet reduction in three years by one third but the number of registered cars decreased essentially because of automatic deletion of vehicles from the register for several reasons (for example, if the vehicle has been registered abroad or if five consecutive years no state technical inspection has been done for the vehicle and certain incentives for vehicle owners to take off the vehicles from the registration were introduced). A smaller decrease in the registered vehicles can be seen in 1995, when re-registration of vehicles was required and old vehicle documents issued during the Soviet times were going to expire. Although there is no computerized information for cars that passed technical inspection in 1995, the tendencies show that the number of re-registered vehicles in 1995 may have been close to the number of vehicles being used in road traffic. The graph also illustrates that if no incentives are given to take vehicles off from registration or in certain cases this is not done automatically, then the number of vehicles may be misleading and has to be taken into account when comparing car ownership for different countries.

\subsubsection{Road network}

Latvia has rather dense road and street network with total length of $70645 \mathrm{~km}$ that includes $15537 \mathrm{~km}$ with bituminous pavement, $53606 \mathrm{~km}$ with crushed stone and gravel pavement and $1502 \mathrm{~km}$ forest roads that have no pavement (Latvian State Roads, 2019). The quality 
of Latvian roads within the EU in 2018 was rated with 3.45 (EU average score is 4.78), which was far better than in 2017 when this rating was only 3.05, although the rank was still 26th out of 28 EU countries compared. Condition of the Latvian road network is pointed out by the EU: "Ratings for Latvia's transport infrastructure are close to the EU average, except for its roads, which are rated poorly" (European Commission, 2019). Important fact that is also pointed out by the EU is that Latvia, as well as Estonia and Lithuania do not have motorways (European Commission, 2018). Average density of roads governed by the Latvian road administration (Latvian State Roads, 2019) is $0.311 \mathrm{~km}$ per $\mathrm{km}^{2}$ and total road network density is $1.131 \mathrm{~km}$ per $\mathrm{km}^{2}$ (Worldstat, n.d.a). It also has to be emphasised that road length per thousand inhabitants in Latvia is $33.14 \mathrm{~km}$ and it is the fourth largest in Europe (Worldstat, n.d.b).

\subsubsection{Traffic intensity and mileage}

Traffic volume on the Latvian road network is continually increasing and in 2019 the average annual daily traffic (AADT) in Latvia reached 6525 vehicles/24h, which was eighth consecutive rise in the average annual traffic volume (Latvian State Roads, 2019). In 2020, the highest traffic volume was recorded on road A10 (Rìga-Ventspils) section between Rīga and Jūrmala, where AADT reached 53352 vehicles/24h. Vehicle total mileage has an increasing trend with certain fluctuations (Fig. 2).

In the early 1990s, the drop in the total mileage came with limited fuel availability and fuel price growth in relation to income. The crisis in 2008 started the next total mileage drop where the total distance covered decreased three consecutive years. The small drop in 2020 may be caused by the pandemics. One of the total mileage increase causes is the availability of vehicles. With the increase in total number of vehicles, on average the vehicle mileage increases. Due to the change in vehicle registration politics, comparing the total number of vehicles registered with the changing mileage is unreasonable; therefore, the $3 \mathrm{D}$ graph for

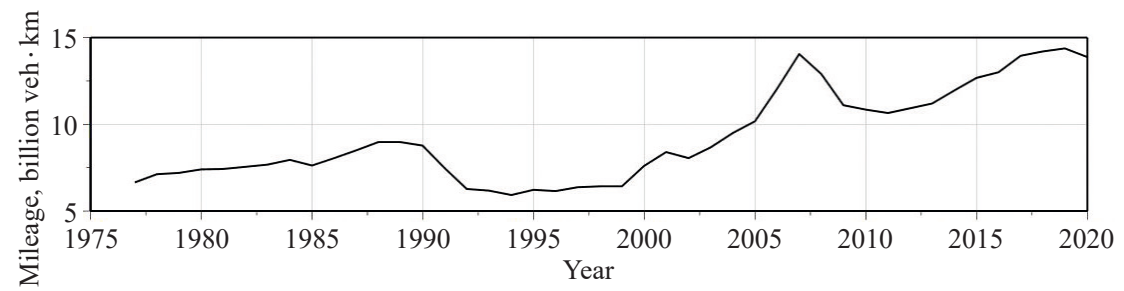

Figure 2. Vehicle total mileage growth in Latvia
Atis Zarins

Road Traffic Safety Development Trends in Latvia 


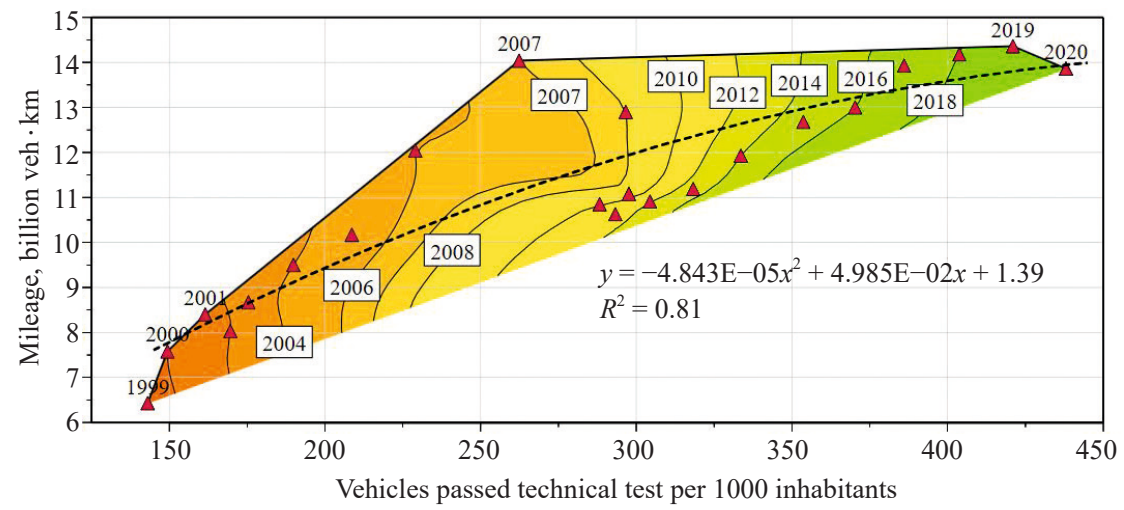

Figure 3. Vehicle total mileage growth in Latvia

total mileage change with the increasing number of vehicles that passed annual technical inspection is shown in Fig. 3. The third dimension is time, where mileage increases along with time up to 2007, then due to the crisis the mileage decreases, from 2008 there is also a slight decrease in vehicle ownership but from 2012 both vehicle ownership and mileage increase up to 2020 where due to the crisis the mileage increase again stops at a similar level as in 2007. The boundary of the coloured chart has no precise physical meaning, it just shows the data zone where the interpolation for isolines has been done.

\subsubsection{Number of inhabitants and drivers}

Population in Latvia is continuously decreasing for the last decades (see Fig. 4). If compared to the maximum numbers in the 1990s, the population has decreased by almost 30\% and gone below 30 people per

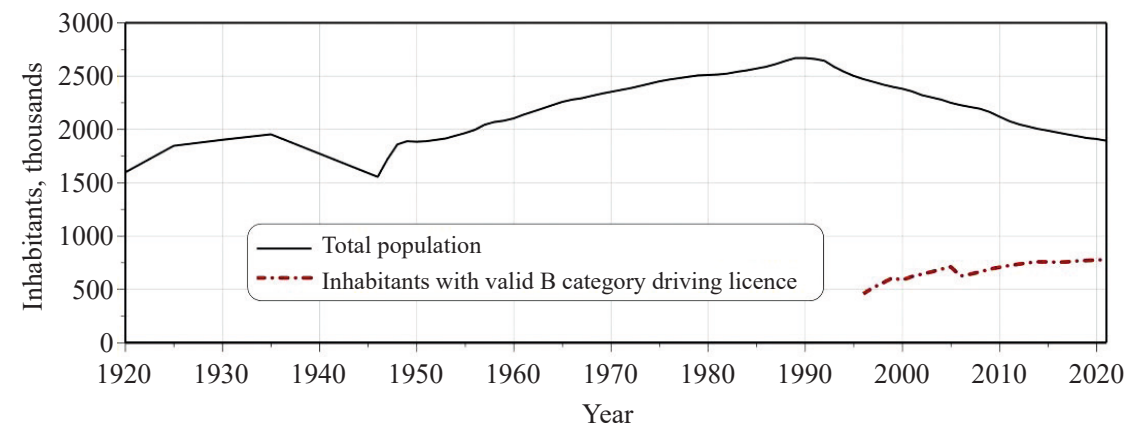

Figure 4. Population and number of valid category B driving licences in Latvia 


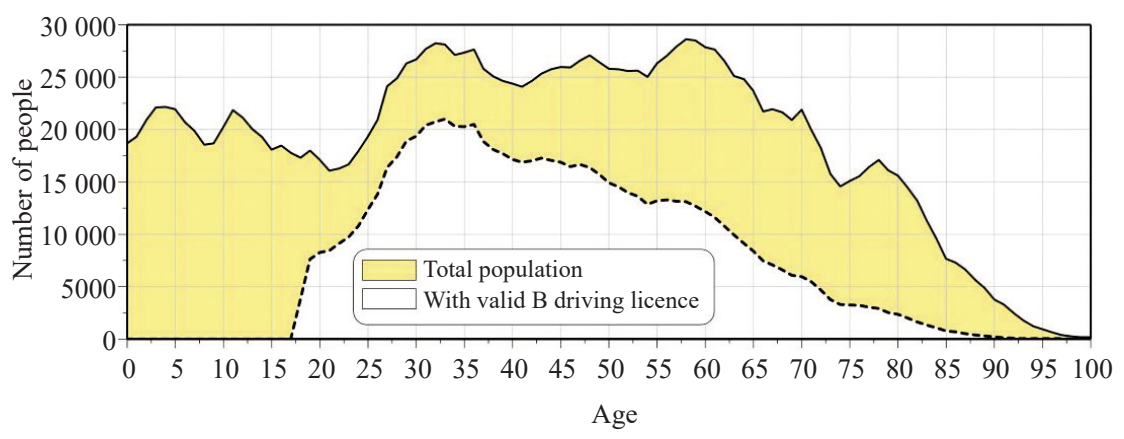

Janis Smirnovs,

Road Traffic Safety Development Trends in Latvia

Figure 5. Population and category B drivers' age distribution

square kilometre (in years 1990 to 1992 there were above 41 people per sq.km) (CSB, 2021).

In contrast, the number of people with valid driving licenses is continuously growing and by the beginning of 2021 above $51 \%$ of people from the age of 18 have a valid category B driving licence (Fig. 4).

The rising trend of people with driving licences can also be seen in Fig. 5 where by the beginning of 2020 people in the age group between 30 and 40 had the highest percentage of category B driving licenses.

The development of the segment of population supposedly understanding the traffic rules for different age groups in Latvia in the $21^{\text {st }}$ century is mapped on the third dimension in Fig. 6 where the numbers on the isolines show the percentage of people with valid category B driving licence.

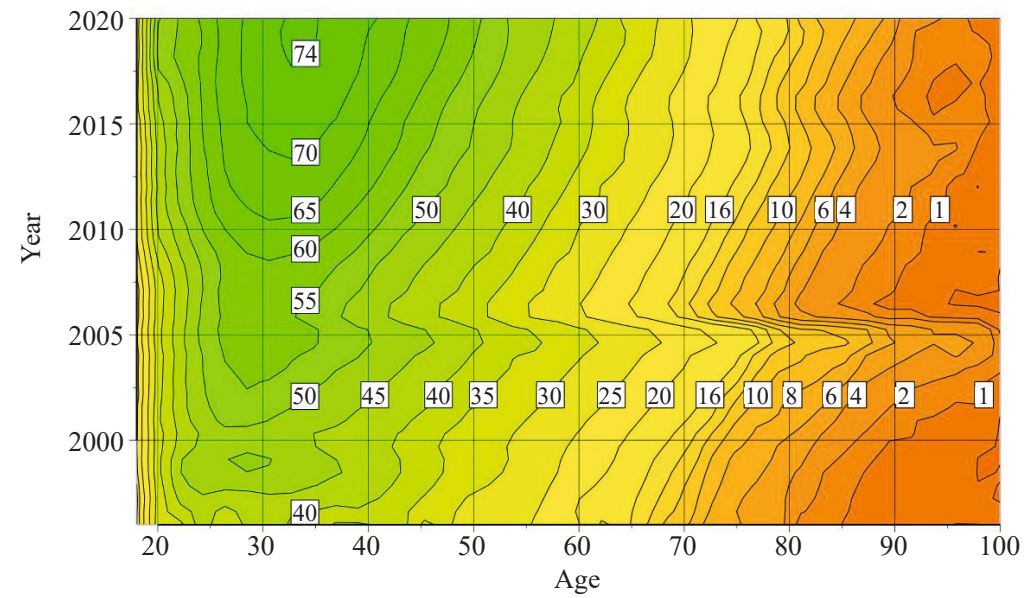

Figure 6. Percentage of Latvian population with valid category

$B$ driving licence 
By the beginning of 2020 close to $75 \%$ of Latvian inhabitants at the age of 34 had the license with this percentage decreasing with the age. The age for the highest percentage of drivers has increased from being 27 in the early 2000s and most probably will continue to increase. The percentage of drivers has also increased in all age groups. If in 2000 only $41 \%$ of people aged 40 had driving licences, then in 2020 the number increased up to $70 \%$, for people aged 50 from 32 to $58 \%$ and even at the age of 80 from 6 to 15\%. The graph shows two fluctuations. The first one was around 2005 because the new Latvian driving licences with 10-year validity were issued from 1995 and part of the inactive drivers did not renew their driving documents. The second ten-year period influenced by the first period can be seen on the graph around 2015 . Notably that the inactive drivers can be seen in all age groups above 30 . A higher number of inhabitants with driving licences may indicate that more people understand the traffic rules and may imagine the traffic situations both from the driver's and pedestrian's perspective, which may facilitate safer traffic.

\subsection{Accident indicators}

Various indicators (absolute and relative, direct and indirect) are used to evaluate road traffic safety. The direct absolute indicators are the number of road accidents, number of fatalities and injuries, losses to national economy that are caused by traffic accidents. Most common direct relative indicators are when absolute indicators are related to the number of inhabitants, vehicles, mileage, or some economic factors. The indirect indicators, determining well known parameters that influence the road safety level, such as seat belt or helmet usage, percentage of mileage covered by sober drivers or drivers not exceeding speed limits, are yet to be measured in Latvia within the framework of the BASELINE project, for which a grant has been awarded by the European Commission; therefore, they are not discussed in this article.

\subsubsection{Number of fatalities and injuries}

Common direct indicator of the traffic safety level is the number of fatalities in road traffic accidents. Number of road traffic accident fatalities in Latvia reached its maximum in 1991 (see Fig. 7). The number of traffic accident fatalities is commonly used for setting road traffic safety targets (European Commission, 2011).

For the most important criterion of road traffic safety which is the number of road fatalities, the statistics show that the turning point recorded in Western European countries in the 1970s (Brüde \& Elvik, 


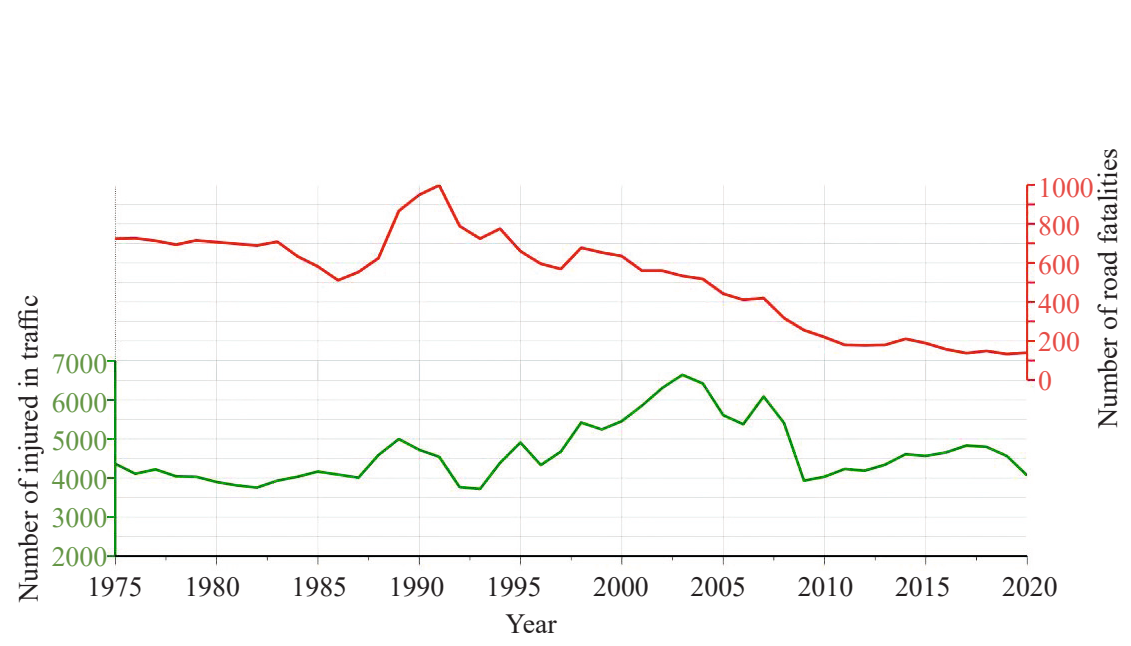

Figure 7. Road traffic accident fatalities in Latvia

2015) happened in Latvia at the beginning of the 1990s only. For the number of injured in road traffic accidents, the situation is slightly different. In this case, the maximum number of injured was reached in 2003 when the level of car ownership reached already 250 vehicles per 1000 inhabitants (see Fig. 6). In 2004, a system of penalty points for traffic rule violation was introduced. Along with active traffic safety campaigns, this led to the reduction in the number of road traffic accident injuries up to 2009. From 2010 when economics started recovering from the economic crisis, the number of injuries started to rise again, while the fatality reduction curve flattened. The Covid-19 crisis gave some reduction in the number of injured but in contrast to the European tendencies (Adminaité-Fodor et al., 2021) the number of fatalities in 2020 went up and fatality statistics for Latvia again sunk down to almost the bottom among the EU countries.

\subsubsection{Vehicle ownership and the numbers of fatalities and injuries}

The highest number of fatalities in road traffic accidents was recorded at the beginning of the 1990s when the level of car ownership was within 90 to 140 cars per 1000 inhabitants. The car ownership expanded with the increased share of western cars in the post-Soviet Latvia after 1990. The number of fatalities depending on car ownership is shown in Fig. 8 along the timeline on the third dimension. From 1991, the car ownership increased until 2009, while the number of fatalities had a clear decreasing tendency. From 2010 with the exclusion of most likely non-used cars from the register described in Section 1.1.1., the tendency must be evaluated separately. Since it has a similar decreasing although more flat character, a single tendency line has been displayed.
Juris Kreicbergs,

Juris Smirnovs,

Aldis Lama,

Janis Smirnovs,

Atis Zarins

Road Traffic Safety Development Trends in Latvia 


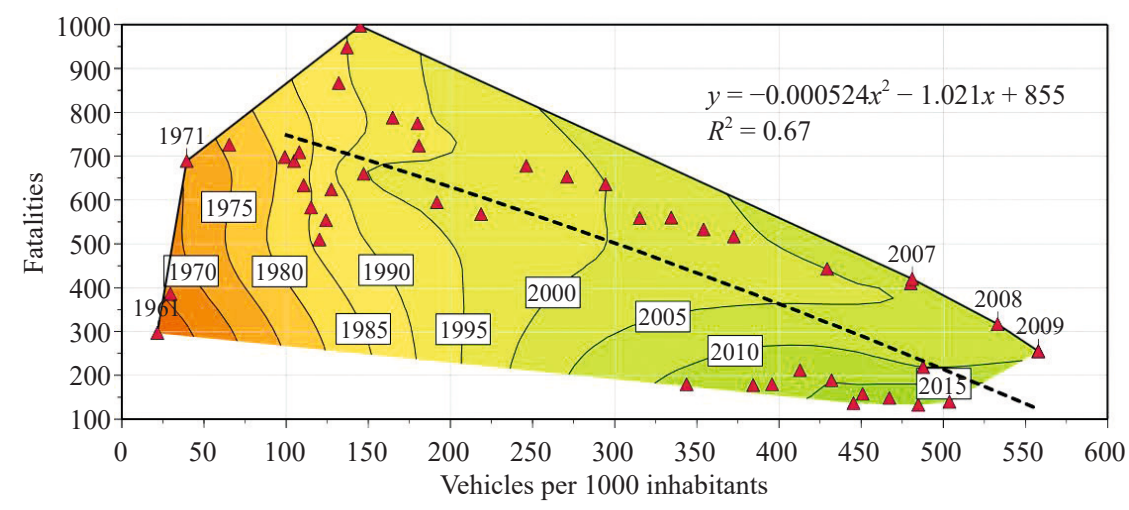

Figure 8. Car ownership and fatality development

The tendencies with the number of injured persons show a clear rise of injuries with a growing car fleet until 2003 (see Fig. 9). This can reflect the situation that many second-hand cars with higher passive safety were imported to Latvia, while the traffic safety risks remained high. With more active traffic safety policies, the number of injured persons started to decrease along with a rising car ownership. This graph also has a separate section from 2010, but since it also shows some decreasing tendency, no separate tendency line has been plotted.

To exclude the influence of vehicle exclusion from the register, the number of fatalities and injuries depending on the number of cars that passed technical inspection is shown in Fig. 10. For road fatalities there is a clear decrease in fatalities along the timeline and along the rising car usage with diminishing decrease ratio closer to 2020. Although the

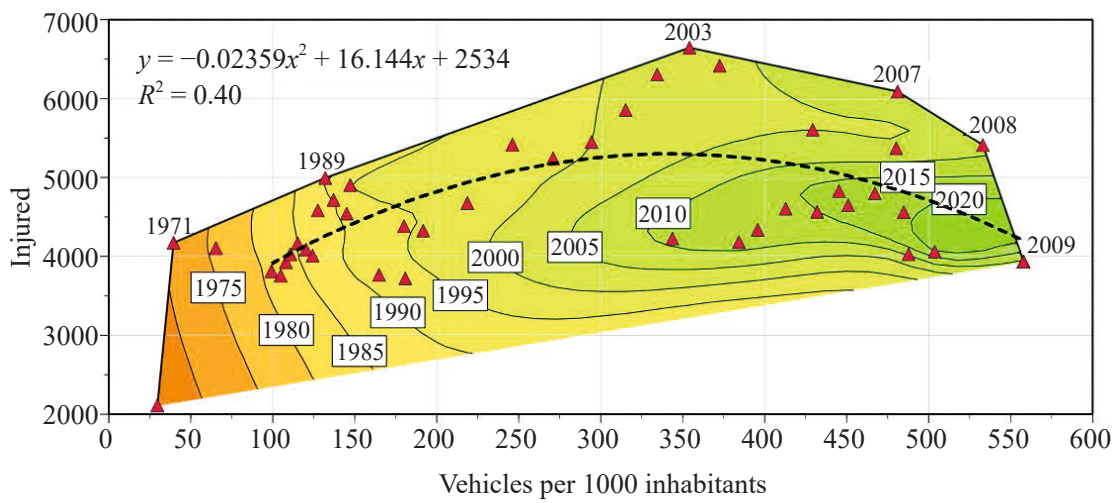

Figure 9. Car ownership and the number of injuries 

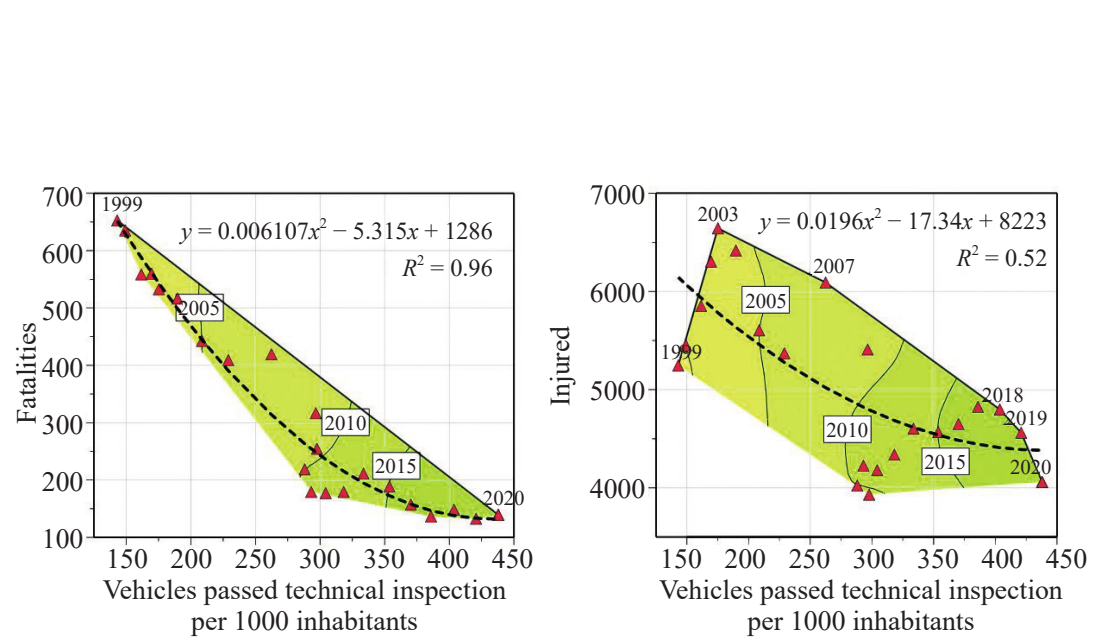

Juris Kreicbergs,

Juris Smirnovs,

Aldis Lama,

Janis Smirnovs,

Atis Zarins

Road Traffic Safety Development Trends in Latvia

Figure 10. Road fatalities and injuries with the increasing number of cars in use

trend line of injuries has a similar character, the data points show the increase before 2003 and another period of increase between 2010 and 2018 confirming that there are other factors apart from car ownership influencing the traffic safety indicators.

\subsubsection{Losses to Latvian economy caused by traffic accidents}

Losses to economy that are caused by road traffic accidents is also a common indicator widely used for the evaluation of the traffic safety level. Usually, the economic losses are calculated as part of the GDP. In 2020 , these losses in Latvia were evaluated being $0.7 \%$ of GDP and in the total sum of losses they accounted for 209 million EUR (see Fig. 11). The decrease in the percentage of losses to GDP was caused both by increasing GDP and non-rising sum of total losses calculated.

The analysis can also be performed the other way around determining impact of GDP on the traffic safety level. Such an analysis shows a clear pattern of decrease in the number of fatalities in Latvia from 1995 to 2020 (see Fig. 12). This conclusion is opposite to the data by Dadgar and Norström's (2016) study that analysed data from 18 OECD

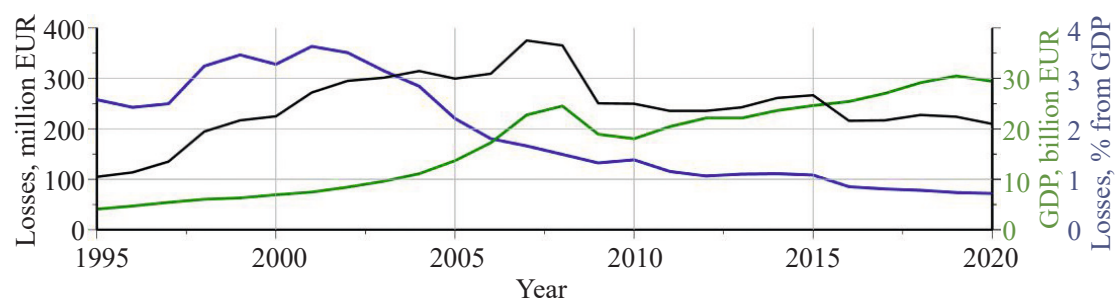

Figure 11. Economic losses from road traffic accidents 


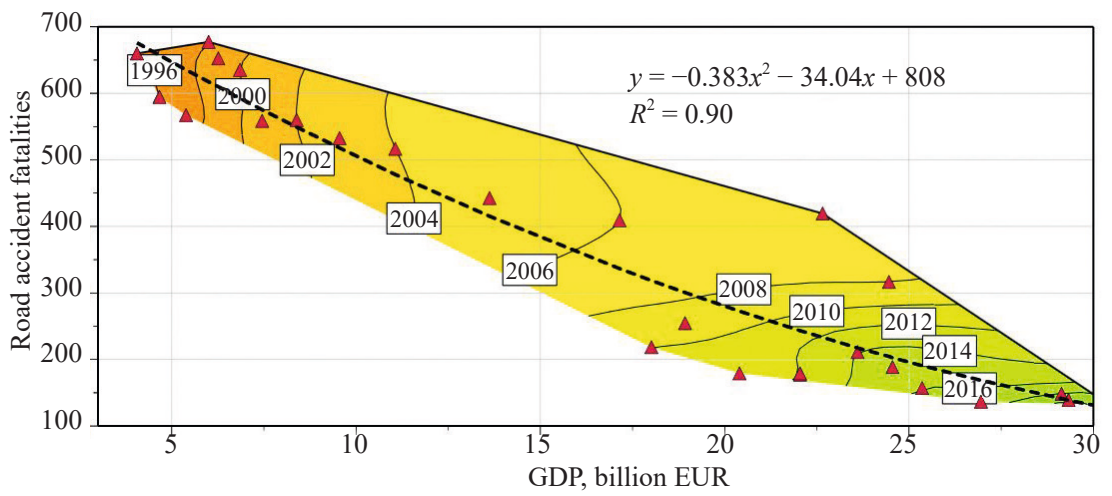

Figure 12. Road accident fatalities and GDP in Latvia from 1996 to 2020

countries and the conclusion was that the increase in GDP leads to an immediate increase in traffic fatalities. This may be caused by fast changes in vehicle in-use technologies in Latvia; therefore, the graph also includes a timeline dimension.

Evaluating how the increase in GDP affects the number of injured persons in road traffic accidents in Latvia (see Fig. 13), again the rise till 2003 can be noticed with later reduction along with rising GDP up till 2006. The highest numbers of injured persons in 2006 and 2007 indicate that an economic activity increases the risks in road traffic. From 2009 till 2018 again there is a tendency of increase in the number of injured persons along with increasing GDP. The reported number of injuries may be influenced by the introduction of mandatory civil liability insurance from 2005 and awareness of drivers that reporting a minor traffic safety

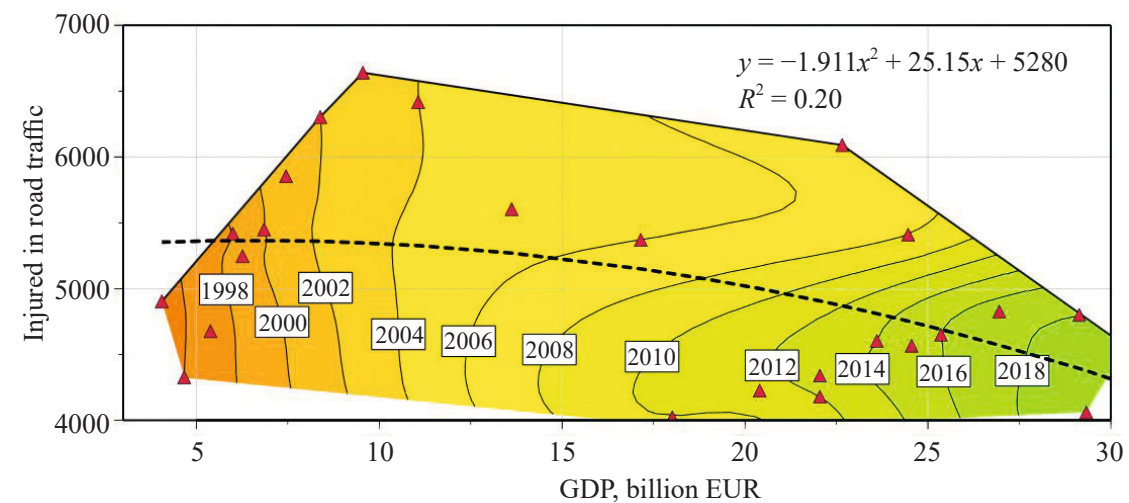

Figure 13. Number of injuries in road traffic with increasing GDP 

in Latvia since 2004 may give more clear results. Nevertheless, in the longer run probably because of the access to safer vehicles owing to a higher income level the decrease in injuries with increased GDP can be clearly seen.

\subsubsection{Traffic safety relative indicators}

The most common two relative road traffic safety indicators are the number of fatalities per number of inhabitants, and the number of fatalities per vehicle mileage (see Fig. 14). Since the early 1990s the situation in Latvia has improved significantly. Despite the fact that over the last decades both of these indicators improved greatly and in 2020 in Latvia there were 10.0 fatalities per million vkm (133.8 in 1991) and 7.3 fatalities per 100000 inhabitants (37.5 in 1991), these results were still too high above the average results of the EU in 2020 being 4.2 fatalities per 100000 inhabitants (Adminaité-Fodor et al., 2021).

One of the established commonly used traffic accident indicators is an accident rate (PIARC, 2019). The accident rate shows the number of annual road traffic accidents per million vehicle kilometres. Almost every road safety discussion in Latvia includes mentioning the change in the number of accidents even if the Vision Zero policy where the focus has been shifted from the number of accidents to the numbers of fatalities and seriously injured (Belin et al., 2012) has been widely analysed and recognised as a leading traffic safety policy. In Latvia, the value of accident rate increased sharply from 1993 (see Fig. 14). Comparing the graphs of fatalities, injured and accident rate it is quite clear that before 1993 there was essential accident underreporting when mostly accidents with casualties were accounted for. In 1993, a computerized traffic accident registration started and this can be seen as a clear increase in the number of accidents. The second fast increase in the accident rate was in 1997 when compulsory third party liability insurance for owners of inland motor vehicles was implemented from September 1997 (Smirnovs \& Lama, 2019). From 2004 after road traffic accidents for the purpose of insurance in certain conditions the involvement of road police for the accident registration was not mandatory; therefore, there was some reduction in an accident rate. Since then the total number of accidents is calculated as the sum of reported accidents by police and insurance companies. Later the drivers got used that even minor accidents could reduce their bonus malus class, which was introduced in 2006, and affect insurance payments; therefore, it became unreasonable to report all minor accidents and the outcome could be seen as the further reduction in an accident rate. 


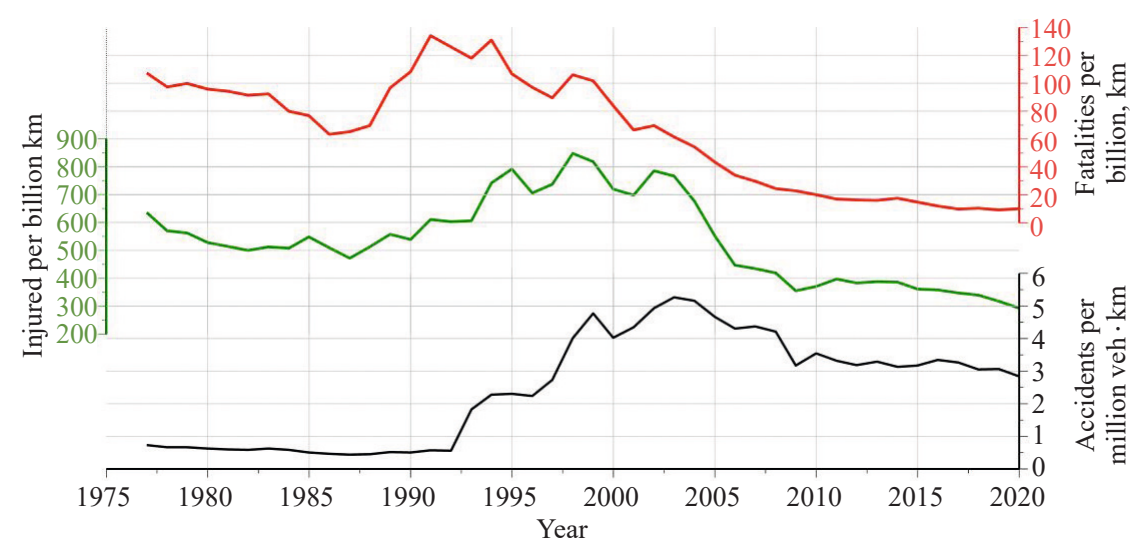

Figure 14. Accident rate, fatalities and number of injured per vehicle mileage in Latvia

Although over the past 10 years there has been a certain trend of stabilization of the accident rate, it is still more reliable to analyse the trends in the change of fatalities and the number of injuries in road traffic.

\section{Discussion}

To evaluate the traffic safety level in each country individually and to carry out international comparisons, it is possible to use the indicators of traffic safety level mentioned in this article: number of fatalities, fatalities per million vehicle kilometres, fatalities per 100000 inhabitants, number of injured and seriously injured, also related to the total mileage and population data, accident rate and absolute number of reported accidents, economic losses caused by road traffic accidents both in absolute figures and relative to GDP (WHO, 2018).

Analysis of traffic safety level in the European countries and Israel was carried out in the scope of DaCoTA project (DaCoTA, 2011), which resulted in the development of Road Safety Index. Based on the initial data characterising each specific country, a further forecast of traffic safety level development was provided. DaCoTA forecast, including the lower and upper boundary, is compared with the actual situation in Latvia (see Fig. 15). Conclusion is that real data statistics stay within the limits of forecast borders of data spread. 
The time period between 2010 and 2020 is also very significant in road safety because of the UN General Assembly announced decade of action on road safety (UN, 2010) with a goal to half road fatalities by 2020 compared to 2010. The target line is also displayed in Fig. 15 indicating that between 2011 and 2013 and in 2017 Latvia was below the target line but finally as all but one EU countries did not succeed reaching the target in 2020 while still staying below the upper forecast boundary of DaCoTA.

Over the past ten years, Latvia has succeeded in considerably improving traffic safety. With the increase in road traffic intensity, the issue of developing road infrastructure becomes more and more important. One of considerable topics in this aspect is the creation of a motorway network. At present, Latvia does not have any motorway network, and specifically in the areas where no such network exists, high fatality rates may be recorded (Eurostat, 2019). Road junctions have the highest possibility for traffic accidents to occur because many types of traffic conflict points are concentrated in junctions (ERSO, 2018). From 2003 to 2020, in Latvia every year from 4 to 15\% of the total number of fatalities were registered in road junctions. The percentage of fatalities on road junctions in Latvia is essentially lower than in the EU where the average percentage in 2016 was above $16 \%$ being on average above 20\% in the time period between 2007 and 2016. The fatality rate on junctions in Latvia in the same period was from 4 to 22 with an average of 10 while 10.7 fatalities per million inhabitants, which was close to the EU average in 2016 meaning that risks at junctions are not worse than in other EU countries.

Vehicle fleet age is one of the most important criteria influencing road traffic safety. The Latvian car fleet can be considered old one: on 1 January 2021 it was slightly above 14 years being close to three years more aged than the average EU car being 11.5 (ACEA, 2021).

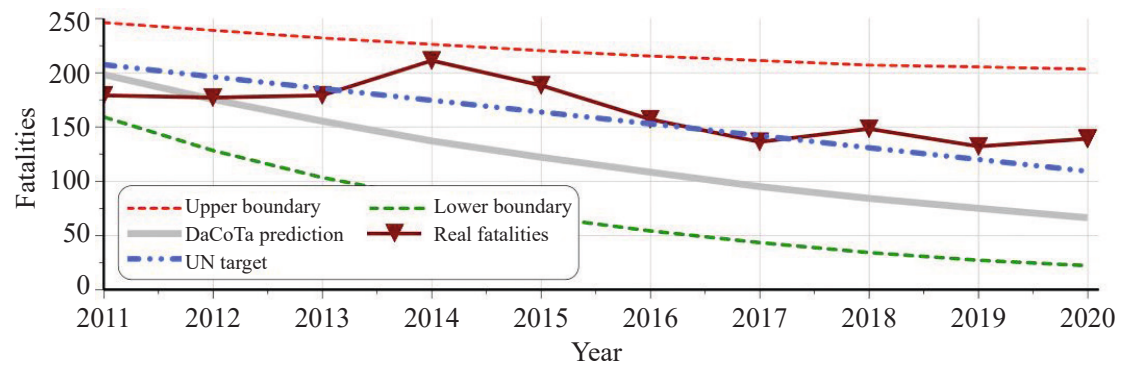

Figure 15. DaCoTA forecast, UN target and real data of road traffic fatalities in Latvia 
Experience and skills of drivers are a significant prerequisite to guarantee traffic safety. On 1 June 2021, there were 870812 valid driving licences, $56.5 \%$ of the licenses were issued to men. In slightly above two decades (from January 2000 to June 2021) the share of female drivers has increased from $29.3 \%$ to $43.5 \%$ (CSDD, 2021b).

With the general aging of the society, the aging of drivers may be seen as well. The mobility needs of the elderly will grow in the future. As a result, elderly road users will transform from a minority group with special needs and habits to one of the largest road user groups. A gradual increase in the proportion of older people is expected by 2050, approximately $28 \%$ of the European population will be 65 years or older (Polders et al., 2015). In Latvia, the share of inhabitants in the age group above 65 years, who have a driving licence, exceeded 35\% in 2021. This phenomenon will set new demands for road designers and road and street equipment. The main future trends will be based on the principles of forgiving road design and improved reflection capacity for road signs and markings (Smirnovs \& Lāma, 2019).

After the regain of independence, drunk driving was a serious issue in road traffic safety: it caused 30.8\% of all fatalities in Latvia in 1995. The first three Latvian national programmes for the improvement of traffic safety paid special attention to combating drunk driving (Smirnovs et al., 1996; Lama et al., 2007; Lama et al., 2013). Thanks to active efforts to combat this problem, it was possible to decrease the share of fatalities caused by drunk driving down to $5 \%$ of the total number of fatalities in 2020 (CSDD, 2021c).

From late 2014 till July 2017, one hundred stationary speed cameras were introduced on Latvian roads (CSDD, 2021). The introduction of cameras contributed to the decrease in the percentage of road traffic accidents with heavy injuries, where speed violation was fixed (see Fig. 16) (CSDD, 2021d).

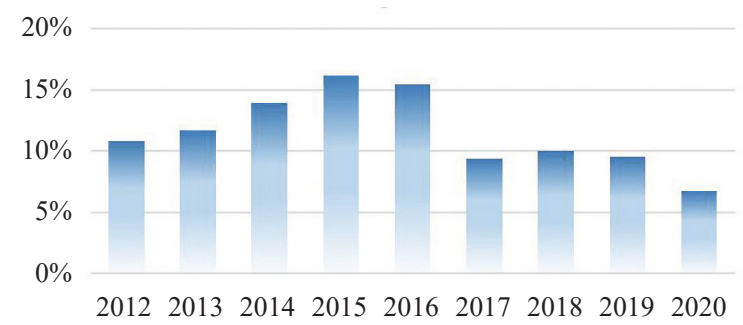

Figure 16. Percentage of road traffic accidents with heavy injuries with fixed speed violation 
Despite this fact, the share of heavy accidents that involve speeding Atis Zarins is still high. The percentage of road traffic accidents with fatalities in 2019 was above $20 \%$ with some decrease in 2020. This confirms the

\section{Conclusions}

Although since the regain of independence in the early 1990s the road safety in Latvia has greatly improved, the road safety statistics for Latvia is still among the worst in the EU countries.

The increase in car ownership does not worsen the road safety probably because of better active and passive safety characteristics of new vehicles.

The gradual increase in the share of people with driving licences in all applicable age categories may have contributed to better understanding of road traffic rules and traffic risks.

While the relative losses compared to GDP from road traffic accidents have been reduced, the losses in absolute figures are still too high and have to encourage more investment in road safety enhancement programmes.

The stabilization of the number of road fatalities in 2011 after the decrease period encourages to look for new measures to be introduced in Latvian road safety programmes.

The European Baseline project measuring the main indirect traffic safety key performance indicators in all EU countries will give some opportunity to analyse what can be done in Latvia at least to move closer to the average traffic safety level in the EU.

\section{REFERENCES}

ACEA (2021). Average age of the EU vehicle fleet, by country. https://www.acea. auto/figure/average-age-of-eu-vehicle-fleet-by-country/

Adminaité-Fodor, D., Carson, J. \& Jost, G. (2021). Ranking EU Progress on Road Safety. European Traffic Safety Council. https://etsc.eu/wp-content/ uploads/15-PIN-annual-report-FINAL.pdf

Belin, M. Å., Tillgren, P. \& Vedung, E. (2012). Vision Zero - a road safety policy innovation. International Journal of Injury Control and Safety Promotion, 19(2), 171-179. https://doi.org/10.1080/17457300.2011.635213

Brüde, U. \& Elvik R. (2015). The turning point in the number of traffic fatalities: Two hypotheses about changes in underlying trends. Accident Analysis \& Prevention, 74, 60-68. https://doi.org/10.1016/j.aap.2014.10.004 
Bureu de Statistique de l'État. Valsts statistiskā pārvalde (1930). Annuiaire Statistique de la Lettonie. Latvijas statistiskā gadagrāmata 1929. Desmitais izdevums (in Latvian and French).

CSB. Central Statistical Bureau of Latvia (2021). Statistics. Population number, its changes and density. https://www.csb.gov.lv/en/statistics/ statistics-by-theme/population/number-and-change/key-indicator/population-number-its-changes-and-density

CSDD. Latvian Road Traffic Safety Directorate (2021a). Statistics. Cel̦u satiksmes negadījumu rezultātā valstij radītie zaudējumi. https://www.csdd.lv/celusatiksmes-negadijumi/celu-satiksmes-negadijumu-rezultata-valstij-raditiezaudejumi (in Latvian)

CSDD. Latvian Road Traffic Safety Directorate (2021b). Number of driver licences. https://www.csdd.lv/en/drivers-of-vehicles/number-of-driver-licences

CSDD. Latvian Road Traffic Safety Directorate (2021c). The Road Traffic Safety statistics. https://www.csdd.lv/en/road-accidents/the-road-traffic-safetystatistics

CSDD. Latvian Road Traffic Safety Directorate (2021d). Stacionārie fotoradari. https://www.csdd.lv/stacionarie-fotoradari/stacionaro-fotordaru-karte (in Latvian)

DaCoTA (2011). Road Safety Development. Latvia. Directorate-General for Mobility and Transport. Retrieved from https:/ec.europa.eu/transport/ road_safety/sites/default/files/specialist/erso/pdf/forecast/dacota-forecast-factsheet-latvia_en.pdf

Dadgar I. \& Norström T. (2016). Short-term and long-term effects of GDP on traffic deaths in 18 OECD countries, 1960-2011. Epidemiology \& Community Health, 71(2),146-153. https://doi.org/10.1136/jech-2015-207138

Elvik R. (2009). Why some road safety problems are more difficult to solve than others. Towards and beyond the 2010 road safety targets - identifying the stubborn issues and their solutions. 22nd ICTCT Workshop in Leeds, Great Britain on 10-23 October 2009. https://www.ictct.net/migrated_2014/ictct_ document_nr_807_Elvik.pdf

ERSO (2018). Traffic Safety Basic Facts 2018. Junctions. European Commission. European Road Safety Observatory. https://ec.europa.eu/transport/road_ safety/sites/default/files/pdf/statistics/dacota/bfs2018_junctions.pdf

European Commission (2011). White Paper. Roadmap to a Single European Transport Area - Towards a competitive and resource-efficient transport system. Brussels. COM (2011) 144 final. 30 p. https://eur-lex.europa.eu/ LexUriServ/LexUriServ.do?uri=COM:2011:0144:FIN:EN:PDF

European Commission (2018). Traffic Safety Basic Facts 2018. Motorways. European Commission, Directorate General for Transport. Retrieved from https://ec.europa.eu/transport/road_safety/sites/roadsafety/files/pdf/ statistics/dacota/bfs2018_motorways.pdf

European Commission (2019). Mobility and Transport. Transport in the European Union. Current Trends and Issues. https://ec.europa.eu/transport/sites/ default/files/2019-transport-in-the-eu-current-trends-and-issues.pdf 
Eurostat (2019). Road safety statistics - characteristics at national and Janis Smirnovs, regional level. https://ec.europa.eu/eurostat/statistics-explained/index. php?title=Road_safety_statistics_-_characteristics_at_national_and_ regional_level\#Motorway_density_and_risk

Eurostat (2020a). Freight transport statistics - modal split. Eurostat Statistics Explained. https://ec.europa.eu/eurostat/statistics-explained/index.php/ Passenger_transport_statistics\#Modal_split_of_inland_passengers

Eurostat (2020b). Passenger Transport Statistics. Eurostat Statistics Explained. https://ec.europa.eu/eurostat/statistics-explained/index.php/Passenger transport_statistics\#Modal_split

Gromule, V. (2020). Autotransports. Nacionālā enciklopēdija Latvija. Rīga. (pp. 589-591) (in Latvian)

Lama A., Smirnovs J. \& Naudzuns J. (2007). Effectiveness of the 2000-2006 National Road Traffic Safety Programme implementation in Latvia. The Baltic Journal of Road and Bridge Engineering, 2(1),13-20.

Lama A., Lama G., Smirnovs J. \& Naudzuns J. (2013). Assessment of the effectiveness of the road traffic safety programme 2007-2013 in Latvia. The Baltic Journal of Road and Bridge Engineering, 8(4), 232-239. https://doi.org/10.3846/bjrbe.2013.30

Latvian State Roads (2019). State Road Network Statistics 2019. https://lvceli.lv/ wp-content/uploads/2020/09/LVC_Statistika_2019.pdf

PIARC (2019). World Road Association. Road Safety Manual. 2003 with on-line update 2019. https://roadsafety.piarc.org/en

Polders E., Brijs T., Vlahogianni E., Papadimitriou E., Yannis G., Leopold F. \& Durso C. (2015). Risks and countermeasures for road traffic of the elderly in Europe. European Commission - Directorate-General for mobility and transport (DG-MOVE), $159 \mathrm{p}$.

Smirnovs J. \& Lāma A. (2019). Road Traffic Safety in Latvia. IOP Conference Series: Earth and Environmental Science, 222, 012001. https://doi.org/10.1088/1755-1315/222/1/012001

Smirnovs J., Naudzuns J., Lama A., Liberts G., Kancevics J. \& Rorbaks G. (1996). Road Safety Improvement Program in Latvia. Proceedings VTI conference No. 4A, Part 4, Road Safety in Europe and Strategic Highway Research Program, Prague, September 20-22, 1995, pp. 73-87.

UN (2010) 64/255. Improving global road safety. Resolution adopted by the General Assembly. United Nations. Retrieved from https://www.who. int/violence_injury_prevention/publications/road_traffic/UN_GA_ resolution-54-255-en.pdf?ua=1

WHO (2018). Global status report on road safety. World Health Organization. https://www.who.int/publications/i/item/9789241565684

Worldstat (n. d. a). Transportation of Latvia. http://en.worldstat.info/Europe/ Latvia/Transportation

Worldstat (n. d. b). List of countries by length of road per thousand persons. http://en.worldstat.info/Europe/List_of_countries_by_Length_of_road_per_ thousand_persons 